\title{
Implementasi Line Balancing untuk Peningkatan Efisiensi di Line Welding Studi Kasus: PT X
}

\author{
Hery Hamdi Azwir ${ }^{1}$, Harry Wahyu Pratomo ${ }^{2}$ \\ ${ }^{1,2)}$ Fakultas Teknik, Jurusan Teknik Industri, Universitas President \\ Jl. Ki Hajar Dewantara, Cikarang Utara, Bekasi, Jawa Barat 17550 \\ Email: ${ }^{1}$ hery.azwir@president.ac.id, ${ }^{2}$ harryndhe.aryani@gmail.com
}

\begin{abstract}
Line balancing is a jobs assignment into a number of work stations that are interrelated in a track or a production line with an objective to minimizing the idle time on the line that is determined by the slowest operation. In line welding 1DY models includes eight work stations where one work station is done by one operator. Problems have been found that these operators have very long idle time and also there is too much wip that creates bottleneck in the production line so these leads to a waste of manpower and time. This waste of manpower and time need to be reduced by determining the optimal amount of labor in order to avoid excessive idle time but work can be done effectively and efficiently. One way to adress imbalance line is to apply line balancing methods. The results of this research shows that the line balancing methods can reduced the waste of time and give solutions for the optimal amount of labor requirements for line welding 1DY models.
\end{abstract}

Keywords: Line Balancing, Workstation, Production Line, Idle Time, Bottleneck.

Abstrak

Keseimbangan lini adalah suatu penugasan sejumlah pekerjaan kedalam stasiun-stasiun kerja yang saling berkaitan dalam suatu lintasan atau lini produksi dengan tujuan meminimumkan waktu menganggur pada lintasan yang telah ditentukan oleh operasi yang paling lambat.Pada line welding model 1DY terdapat 8 stasiun kerja dimana 1 stasiun kerja dikerjakan oleh 1 operator. Disaat pekerjaan berlangsung sering terjadi waktu menganggur yang sangat lama untuk setiap operator dalam melakukan pekerjaannya, serta adanya penumpukan barang pada aliran produksi (bottleneck), menyebabkan terjadinya pemborosan tenaga kerja. Dengan adanya pemborosan waktu tersebut, perlu dilakukan perhitungan ulang penentuan jumlah tenaga kerja yang optimal agar tidak terjadi waktu menganggur yang berlebihan dan pekerjaan dapat dilakukan dengan efektif dan efisien. Salah satu cara untuk mengatasi ketidakseimbangan lini adalah dengan melakukan keseimbangan pada lini perakitan menggunakan metode-metode keseimbangan lini.Hasil penelitian ini menghasilkan metode keseimbangan lini yang optimal dan jumlah kebutuhan tenaga kerja optimal yang dapat digunakan untuk line welding model 1DY.

Kata kunci: Keseimbangan Lini, Stasiun Kerja, Lini Produksi, Waktu Menganggur, Bottleneck.

\section{Pendahuluan}

\section{Latar belakang Masalah}

PT. $\quad X$ adalah perusahaan yang memproduksi knalpot (muffler) sepeda motor merk Yamaha. Model knalpot 1DY adalah model knalpot untuk sepeda motor type New Jupiter Z. Dengan adanya penumpukan barang pada aliran produksi (bottleneck), operator kerja yang tidak ada di stasiun kerjanya pada saat jam kerja, secara otomatis terjadi lost time jam kerja pada schedule produksi. Hal ini berdampak negatif pada keuntungan yang dihasilkan perusahaan, yang dapat diketahui dari jumlah biaya yang dikeluarkan perusahaan untuk gaji karyawan, biaya makan karyawan, tunjangan transportasi dan lain-lain.

Pembengkakkan biaya tersebut karena adanya penggunaan tenaga kerja yang tidak tepat, dapat diminimalkan dengan penerapan strategi dan perencanaan produksi yang tepat, mengingat model 1DY diproduksi secara massal. Dalam produksi massal dimana metode dan elemen-elemen kerja yang sama dilakukan berulang-ulang, efficiency line yang 
rendah dan balance delay yang tinggi memberi dampak negatif secara langsung terhadap performa produksi suatu perusahaan secara keseluruhan. Data jumlah tenaga kerja yang digunakan sebanyak 8 operator per bulan memperlihatkan bahwa sumber daya yang ada belum dikelola secara maksimal. Salah satu cara untuk mengatasi ketidakseimbangan line adalah dengan melakukan keseimbangan pada lini perakitan (line balancing).

Line balancing merupakan metode untuk menyeimbangkan penugasan beberapa elemen kerja dari suatu lintasan perakitan ke stasiun kerja untuk meminimumkan banyaknya stasiun kerja dan meminimumkan total waktu menunggu (idle time) pada keseluruhan stasiun kerja pada tingkat output tertentu (Boysen et al, 2007), yang dalam penyeimbangan tugas ini, kebutuhan waktu per unit produk yang dispesifikasikan untuk setiap tugas dan hubungan sekuensial harus dipertimbangkan, sehingga memperoleh suatu arus produksi yang lancar dalam rangka mendapatkan utilisasi yang tinggi atas fasilitas, tenaga kerja maupun peralatan.

\section{Rumusan Masalah}

Dari latar belakang permasalahan, data serta pengolahan data yang didapatkan dari line welding 1DY, dapat diuraikan rumusan masalah penelitian sebagai berikut:

a. Bagaimana meningkatkan performansi line welding 1DY yang ada saat ini?

b. Bagaimana mendapatkan model keseimbangan lintasan yang lebih efisien untuk line welding 1DY?

c. Berapakah jumlah kebutuhan operator/tenaga kerja (manpower) yang ideal untuk line welding 1DY?

\section{Tujuan dan Manfaat Penelitian}

Dari rumusan masalah diatas, maka tujuan yang ingin dicapai atas dilakukannya penelitian ini adalah sebagai berikut :

a. Mendapatkan rancangan model keseimbangan lintasan (jumlah stasiun dan alokasi elemen kerja) yang efisien untuk line welding 1DY.

b. Menentukan jumlah operator (tenaga kerja) yang optimal untuk line welding 1DY.

Adapun manfaat yang diharapkan dari penelitian ini adalah:

1. Memberikan rekomendasi untuk mengoptimalkan penggunaan sumber daya manusia (tenaga kerja) di PT. X.

2. Sebagai pengembangan ilmu bidang industri dalam kajian penggunaan tenaga kerja yang optimal.

\section{Batasan Masalah}

Sumber daya dan waktu penelitian yang terbatas, membuat adanya beberapa batasan 58 pembahasan dalam penelitian ini, antara lain :

a. Penelitian hanya dilakukan satu jenis produk knalpot yaitu model 1DY.

b. Pengambilan data penelitian diambil selama 3 bulan produksi yaitu bulan Agustus, bulan September dan bulan Oktober 2015.

c. Aspek yang diambil dalam penelitian ini adalah waktu siklus elemen kerja pada line welding 1DY.

d. Waktu baku yang digunakan pada penelitian ini adalah waktu baku yang dimiliki manajemen PT. $X$ dimana waktu baku tersebut sudah mempertimbangkan performance rating (faktor penyesuaian) dan allowance (faktor kelonggaran) serta sesuai dengan waktu efektif kerja PT. X.

e. Operator kerja yang diamati adalah operator kerja dengan tingkat kemampuan dan keterampilan rata-rata dalam menyelesaikan pekerjaannya.

\section{Asumsi}

Untuk mempermudah penelitian, ada beberapa asumsi yang ditetapkan dalam pembuatan model line balancing. Asumsi tersebut antara lain:

a. Cara kerja yang digunakan sudah benar.

b. Tidak terjadi kendala dalam proses produksi seperti keterlambatan supply part, kerusakan mesin, alat kerja ataupun material handling.

c. Tidak adanya part NG didalam produksi.

d. 1 stasiun kerja dikerjakan oleh 1 operator sehingga total jumlah operator sama dengan jumlah stasiun kerja.

e. Pergantian operator disaat kerja jika ada sesuatu hal maka harus ijin terlebih dahulu ke sub-leader dan sub-leader yang akan menggantikan operator sementara waktu.

\section{Metode Penelitian}

\section{Tahapan Penelitian}

Perancangan line balancing ini, dilakukan dengan beberapa tahapan, antara lain observasi awal, identifikasi masalah, studi pustaka, pengumpulan dan pengolahan data, analisis dan perbaikan, yang kemudian menghasilkan kesimpulan dan rekomendasi.

\section{Teknik Pengumpulan Data}

Teknik pengumpulan data sendiri dilakukan dengan dua cara yaitu dengan pengumpulan data secara langsung dari perusahaan dan wawancara terhadap pihakpihak yang berhubungan dengan proses kerja.

\section{Metode yang Digunakan}

Dalam penelitian ini, ada 3 metode yang digunakan dalam perancangan line balancing ini yaitu: 
1. Metode Helgeson-Birnie

Elsayed dan Boucher (1994) menjelaskan penyeimbangan lintasan metode ini dapat dilakukan melalui beberapa langkah berikut:

a. Menyusun precedence diagram

b. Menentukan posisi peringkat (positional weight) untuk setiap elemen kerja (posisi peringkat sebuah operasi yang saling berhubungan dari waktu alur terpanjang dari permulaan operasi hingga akhir jaringan).

c. Membuat urutan elemen kerja dari posisi peringkat teratas berdasarkan posisi peringkat pada langkah nomor dua.

d. Proses penempatan elemen-elemen kerja pada stasiun kerja berdasarkan posisi peringkat dan urutan paling tinggi ditempatkan pada urutan pertama.

e. Jika pada stasiun kerja terdapat waktu sisa setelah penempatan sebuah operasi, tempatkan operasi dengan urutan selanjutnya pada stasiun kerja, sepanjang operasi tidak melanggar hubungan precedence, waktu stasiun kerja tidak diizinkan melebihi waktu siklus.

Metode Helgeson-Birnie lebih dikenal dengan nama bobot posisi peringkat (Rank Positional Weight).

2. Metode Kilbridge-Wester Heuristics

Elsayed dan Boucher (1994) menjelaskan penyeimbangan lintasan perakitan metode Kilbridge-Wester Heuristics dapat dilakukan dengan melalui langkah-langkah sebagai berikut:

a. Membagi region atau daerah dari kiri ke kanan. Jika memungkinkan letakkan elemen kerja pada region paling kanan.

b. Tentukan peringkat untuk setiap elemen kerja pada setiap region berdasarkan waktu maksimum ke waktu minimum.

c. Berdasarkan ketentuan yang menyebutkan bahwa region atau daerah kiri terlebih dahulu dan peringkat operasi dalam region pada langkah $\mathrm{b}$ lakukan pembebanan elemen kerja ke dalam stasiun kerja dengan ketentuan tidak melanggar precedence diagram dan waktu siklus tidak melebihi waktu siklus aktual.

3. Metode Moddie Young

Elsayed dan Boucher (1994) menjelaskan tentang dua fase yang terdapat dalam iterasi Moodie Young antara lain:

1) Fase pertama pada elemen kerja ditugaskan ke stasiun kerja secara berurutan pada assembly line dengan aturan kandidat terbesar (largestcandidate). Aturan largest-candidate terdiri atas penugasan elemen-elemen yang memungkinkan (tidak ada larangan precedences) dengan urutan menurun. Dengan kata lain jika dua elemen memungkinkan untuk penugasan pada satu stasiun, elemen yang memiliki waktu lebih besar ditugaskan terlebih dahulu. Setelah tiap elemen ditugaskan, elemen-elemen yang memungkinkan dipertimbangkan dalam urutan waktu yang menurun dalam penugasan selanjutnya. Menggunakan matriks $P$ (untuk mengindikasikan elemen kerja pendahulu) dan matriks $\mathrm{F}$ (mengindikasikan elemen kerja yang mengikuti) sebagai prosedur penugasan.

2) Fase kedua dilakukan dengan cara mendistribusikan waktu menganggur secara merata pada semua stasiun melalui mekanisme jual dan transfer dari elemen-elemen antar stasiun (mematuhi batasan-batasan precedence). Tahapan yang harus dilakukan pada fase kedua ini adalah:

a. Menentukan waktu stasiun kerja terbesar dan terkecil dari balance pada fase satu.

b. Menentukan GOAL dengan rumus: $\mathrm{GOAL}=\frac{\mathrm{ST}_{\text {max }}-\mathrm{ST}_{\text {min }}}{2} \quad$ Pers. 1

c. Mengelompokkan semua elemen tunggal pada $\mathrm{ST}_{\max }$, yang mempunyai waktu lebih kecil dari GOAL dan tidak melanggar precedence diagram jika ditransfer ke $\mathrm{ST}_{\min }$.

d. Menentukan semua trade yang memungkinkan dari $\mathrm{ST}_{\max }$ untuk elemen tunggal dari $\mathrm{ST}_{\min }$ sehingga reduksi di $\mathrm{ST}_{\max }$ dan subsequent gain dalam $\mathrm{ST}_{\min }$ bernilai kurang dari 2 kali GOAL.

e. Memindahkan trade atau transfer terindikasi oleh kandidat dengan perbedaan absolut terkecil antar dirinya dengan GOAL.

f. Jika tidak ada trade atau transfer yang memungkinkan antara stasiun terbesar dan stasiun terkecil, coba trade dan transfer antara stasiun terperingkat dengan urutan berikut: dengan $\mathrm{N}(\mathrm{N}$ ke- stasiun terperingkat yang memiliki waktu menganggur terbesar), $\mathrm{N}$ $1, \ldots, 3,2,1$.

g. Jika trade atau transfer masih tidak memungkinkan, letakkan larangan yang dibebankan oleh nilai GOAL dan coba, melalui langkah satu sampai enam, untuk mendapatkan trade atau transfer yang tidak akan meningkatkan nilai stasiun manapun melebihi cycle time aslinya. 


\section{Parameter Performansi Line}

Untuk pengukuran performansi line pada penelitian ini, Elsayed dan Boucher (1994) menjelaskan beberapa parameter yang dapat digunakan untuk mengukur performansi assembly line antara lain:

a. Line Efficiency (LE) merupakan rasio dari total waktu stasiun kerja terhadap waktu siklus (cycle time) dikalikan dengan jumlah stasiun kerja (workstation).

$$
\begin{aligned}
& L E=\frac{\sum_{i=1}^{K} S T_{i}}{(K)(C T)} \times 100 \quad \text { Pers. } 2 \\
& \text { Dimana: } \\
& \mathrm{STi}=\text { Waktu stasiun } \mathrm{i} \\
& \mathrm{K}=\text { Jumlah stasiun kerja } \\
& \mathrm{CT}=\text { Waktu siklus atau cycle time }
\end{aligned}
$$

b. Balance Delay (BD)

Balance Delay adalah rasio antara waktu menunggu dalam lintasan perakitan dengan waktu yang tersedia pada lini perakitan.

$$
\begin{aligned}
& B D=\frac{(K \times C T)-\sum_{i=1}^{n} t i}{(K \times C T)} \times 100 \% \text { Pers. } 3 \\
& \text { Dimana: } \\
& \mathrm{K} \quad=\text { Jumlah stasiun kerja } \\
& \mathrm{CT}=\text { Waktu siklus } \\
& \sum \mathrm{ti}=\text { Jumlah dari seluruh waktu operasi } \\
& \mathrm{BD}=\text { Balance delay }(\%)
\end{aligned}
$$

c. Smoothness Index (SI)

Smoothness index atau indeks penghalusan yaitu cara untuk mengukur waktu tunggu relatif dari suatu lini perakitan. Nilai minimum dari smoothness index adalah 0 yang mengindikasikan keseimbangan sempurna. Semakin mendekati 0 nilai smoothness index suatu lini perakitan, maka semakin seimbang lini perakitan tersebut, artinya pembagian elemen kerja cukup merata pada lini perakitan tersebut.

$S I=\sqrt{\sum_{i=1}^{K}\left(S T_{\max }-S T_{i}\right)^{2}}$

Pers. 4

Dimana:

$S T_{\max }=$ Waktu maks stasiun kerja ke-i

$\mathrm{STi}=$ Waktu stasiun di stasiun kerja ke-i

$\mathrm{K}=$ Jumlah stasiun kerja

\section{Menghitung Takt Time}

Takt time dapat dijelaskan sebagai waktu yang dibutuhkan untuk memproduksi satu unit produk berdasarkan pada kecepatan permintaan pelanggan. (Wignjosoebroto, 2003).

Takt Time $=\frac{\text { Waktu produksi } / \text { hari }}{\text { Permintaan harian }} \quad$ Pers. 5

\section{Menghitung Jumlah Stasiun Kerja}

Stasiun kerja adalah tempat pada lini perakitan dimana sebuah proses perakitan atau lebih dilakukan. Menentukan jumlah stasiun kerja dapat ditetapkan dengan rumus: Jumlah Stasiun Kerja $=\frac{\sum_{i=1}^{N} \mathrm{ti}}{W S i} \quad$ Pers. 6 Dimana:

$$
\begin{array}{ll}
\mathrm{N} & =\text { Jumlah Elemen Kerja } \\
\mathrm{ti} & =\text { Waktu Elemen Kerja Ke-i } \\
\mathrm{Wsi} & =\text { Waktu Siklus }
\end{array}
$$

\section{Hasil Pembahasan}

Purnomo (2004) menjelaskan jika perencanaan dan pengaturan yang tidak tepat dapat mengakibatkan setiap stasiun kerja pada lintas perakitan memiliki kecepatan produksi yang berbeda sehingga terjadi penumpukan material di antara stasiun kerja yang tidak berimbang kecepatan produksinya (bottleneck). Oleh karena itu perlu dilakukan usaha-usaha untuk menyeimbangkan lintasan (line balancing).

\section{Analisis Data}

Data Tabel 1 dibawah ini merupakan data waktu siklus baku yang telah ditetapkan manajemen PT. $X$ yang diambil perhitungannya oleh pihak departemen engineering PT. X (dalam satuan detik).

Tabel 1. Waktu siklus elemen kerja line welding 1DY

\begin{tabular}{|c|l|c|}
\hline $\begin{array}{c}\text { Elemen } \\
\text { kerja }\end{array}$ & \multicolumn{1}{|c|}{ Proses } & Ws \\
\hline 1 & Roll Body 1-1 & 7.67 \\
\hline 2 & Weld Body 1-1 & 20 \\
\hline 3 & Forming Body 1-1 & 9.72 \\
\hline 4 & Weld Spot Body 1-1 x body 2-1 & 10 \\
\hline 5 & Robot 1 & 23.78 \\
\hline 6 & Robot 2 & 23.54 \\
\hline 7 & Marking & 25.4 \\
\hline 8 & SPM 1 & 24.86 \\
\hline 9 & SPM 2 & 35.23 \\
\hline 10 & Spm Final & 36.82 \\
\hline 11 & Robot 3 & 34.69 \\
\hline 12 & Weld SPM Body 1-1 x Body 1-2 & 35.41 \\
\hline 13 & Robot 4 & 33.76 \\
\hline 14 & Robot 5 & 39.77 \\
\hline 15 & Leaktest & 21.31 \\
\hline 16 & Insp Jig & 15 \\
\hline 17 & Clean Spatter & 35.41 \\
\hline
\end{tabular}

Selain data waktu baku, diperlukan juga data permintaan untuk perancangan line balancing. Data dibawah ini merupakan data permintaan produksi line welding 1DY.

Tabel 2. Jumlah permintaan

\begin{tabular}{|c|c|c|c|}
\hline Bulan & Permintaan & $\begin{array}{c}\text { Hari } \\
\text { kerja }\end{array}$ & $\begin{array}{c}\text { Waktu kerja } \\
\text { tersedia } \\
\text { (menit) }\end{array}$ \\
\hline Agustus & 6900 & 20 & 9100 \\
\hline September & 7400 & 20 & 9100 \\
\hline Oktober & 8500 & 22 & 10010 \\
\hline
\end{tabular}




\section{Analisis Kondisi Awal}

Untuk mempermudah analisis pada kondisi awal, maka dibuat ilustrasi kondisi layout awal line welding 1DY yang terdiri dari 8 stasiun kerja dengan 8 operator kerja.

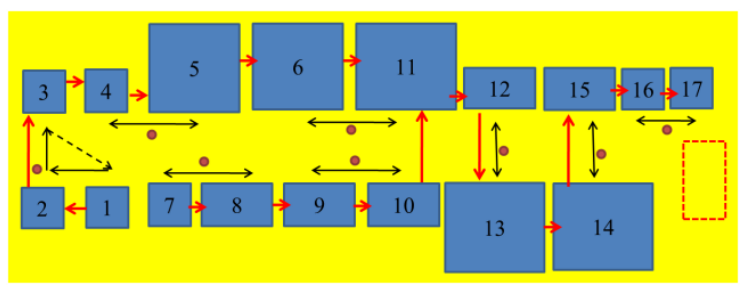

Gambar 1. Layout kondisi awal line welding 1DY

Dimana:

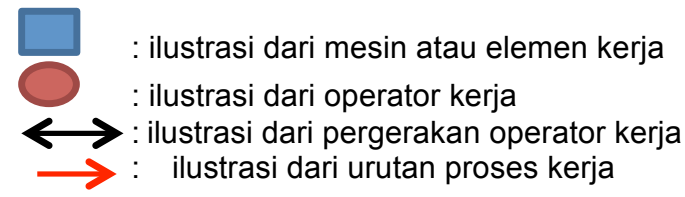

Terlampau lama waktu operator menganggur antar stasiun dengan waktu terlama stasiun membuat line tersebut kurang dalam hal efisiensi. Untuk mengetahui efficiency line tersebut, kita perlu mengetahui cycle time produk saat ini. Waktu siklus (cycle time) harus lebih besar atau sama dengan waktu stasiun dimana $\mathrm{Ti} \leq \mathrm{STi} \leq \mathrm{CT}$ (Elsayed dan Boucher, 1994). Waktu siklus terbesar pada penelitian ini dimiliki oleh stasiun kerja 5 (dalam satuan detik) hal ini dapat dilihat dari tabel 3 .

Tabel 3. Idle time berdasarkan waktu stasiun kerja terlama

\begin{tabular}{|c|c|c|}
\hline $\begin{array}{c}\text { Stasiun } \\
\text { kerja }\end{array}$ & Ws stasiun kerja & Idle time \\
\hline 1 & 37.39 & 34.66 \\
\hline 2 & 33.78 & 38.27 \\
\hline 3 & 58.23 & 13.82 \\
\hline 4 & 50.26 & 21.79 \\
\hline 5 & 72.05 & 0 \\
\hline 6 & 69.17 & 2.88 \\
\hline 7 & 61.08 & 10.97 \\
\hline 8 & 50.41 & 21.64 \\
\hline$\Sigma$ & 432.37 & \multicolumn{1}{|c}{} \\
\cline { 1 - 3 } & \multicolumn{2}{|c}{}
\end{tabular}

Maka, perhitungan line efficiency, balance delay dan smoothness index pada kondisi awal adalah sebagai berikut:

\section{Line Efficiency}

$\mathrm{LE}=\frac{\sum_{\mathrm{i}=1}^{\mathrm{K}} S \mathrm{~T}_{\mathrm{i}}}{(\mathrm{K})(\mathrm{CT})} \times 100 \%$

$$
\begin{aligned}
& =\frac{37.39+33.78+\ldots+50.41}{8 \times 72.05} \times 100 \% \\
& =75.01 \%
\end{aligned}
$$

Balance Delay

$$
\begin{aligned}
\mathrm{BD} & =\frac{(\mathrm{K} \times \mathrm{CT})-\sum_{\mathrm{i}=1}^{\mathrm{n}} \mathrm{ti}}{(\mathrm{K} \times \mathrm{CT})} \times 100 \% \\
& =\frac{(8 \times 72.05)-432.37}{8 \times 72.05} \times 100 \% \\
& =24.98 \%
\end{aligned}
$$

\section{Smoothness Index}

$$
\begin{aligned}
\text { SI } & =\sqrt{\sum_{i=1}^{K}\left(\mathrm{ST}_{\max }-\mathrm{ST}_{\mathrm{i}}\right)^{2}} \\
& =\sqrt{34.66^{2}+\ldots+21.64^{2}} \\
& =62.67
\end{aligned}
$$

Hasil analisis menunjukan performansi lini perakitan yang kurang baik pada kondisi line welding 1DY saat ini.

Berdasarkan perhitungan analisis kondisi awal, terdapat permasalahan dari indikator performansi line welding 1DY yaitu belum optimalnya performansi line welding 1DY.

\section{Hasil Analisis Kondisi Awal}

Berdasarkan identifikasi penyebab masalah yang telah dijelaskan dapat disimpulkan bahwa untuk memperbaiki performansi line welding 1DY maka diperlukan metode line balancing yang dapat mengoptimalkan performansi line welding 1DY.

\section{Perancangan Metode Line Balancing}

Salah satu cara yang dapat dilakukan untuk menyeimbangkan lintasan perakitan adalah dengan mengatur ulang susunan pengelompokan elemen kerja. Elsayed dan Boucher (1994) menjelaskan beberapa hal yang menjadi batasan dalam pengelompokan elemen kerja antara lain:

a. Hubungan precedence

b. Jumlah stasiun kerja tidak boleh lebih besar dari jumlah elemen kerja atau operasi $(1 \leq \mathrm{K} \leq \mathrm{N})$.

c. Waktu siklus lebih besar atau sama dengan waktu maksimum dari waktu stasiun dan waktu elemen kerja Ti. Waktu stasiun tidak boleh melebihi cycle time ( $\mathrm{Ti}$ $\leq \mathrm{STi} \leq \mathrm{CT}$ ).

\section{Perhitungan Takt Time}

Bulan Agustus dan bulan September terdapat waktu kerja efektif sebesar 9100 menit dengan target produksi sebesar 6900 pieces pada bulan Agustus serta 7400 pieces pada bulan September sedangkan pada bulan Oktober terdapat waktu kerja efektif sebesar 10010 menit dengan jumlah produksi 8500 pieces hal ini dapat dilihat dari tabel 2 . 
Berdasarkan data tersebut takt time dihitung dengan persamaan berikut.

$$
\begin{aligned}
\mathrm{T} 1 \text { (Agustus) } & =\frac{\text { Total waktu kerja tersedia }}{\text { Permintaan }} \\
& =\frac{9100 \times 60}{6900} \\
& =79.13 \mathrm{detik} / \text { produk }
\end{aligned}
$$

$\mathrm{T} 2($ September $)=\frac{\text { Total waktu kerja tersedia }}{\text { Permintaan }}$

$$
\begin{aligned}
& =\frac{9100 \times 60}{7400} \\
& =73.78 \text { detik/produk }
\end{aligned}
$$

$$
\begin{aligned}
\text { T3 (Oktober) } & =\frac{\text { Total waktu kerja tersedia }}{\text { Permintaan }} \\
& =\frac{10010 \times 60}{8500} \\
& =70.65 \mathrm{detik} / \text { produk }
\end{aligned}
$$

Maka, acuan takt time yang di ambil adalah rata-rata dari tak time pada 3 bulan tersebut yaitu sebesar 74.55 detik/produk.

$$
\begin{aligned}
\mathrm{T}(\text { total }) & =\frac{\mathrm{T} 1+\mathrm{T} 2+\mathrm{T} 3}{3} \\
& =\frac{79.13+73.78+70.65}{3} \\
& =74.55 \text { detik/produk }
\end{aligned}
$$

\section{Perhitungan Jumlah Stasiun Kerja}

Jumlah stasiun kerja sangat dibutuhkan perhitungannya untuk menentukan perancangan keseimbangan lintasan agar hasilnya lebih maksimal. Adapun penentuan jumlah stasiun kerja dapat di dilihat dari tabel 1 waktu siklus elemen kerja line welding 1DY.

Berdasarkan tabel tersebut, penentuan jumlah stasiun kerja dapat dihitung dengan persamaan berikut.

Jumlah stasiun kerja $=$

$$
\begin{aligned}
& =\frac{\sum_{\mathrm{i}=1}^{\mathrm{N}} \mathrm{ti}}{\text { Takt Time }} \\
& =\frac{(7.67+20+9.72+\cdots+15+35.41)}{74.55}
\end{aligned}
$$

$=5.79 \approx$ dibulatkan menjadi 6 stasiun kerja.

\section{Metode Helgeson-Birnie}

Hasil perhitungan parameter performansi line dari metode Helgeson-Birnie adalah sebagai berikut:

Line Efficency

$$
\mathrm{LE}=\frac{72.79+72.18 \ldots+71.72}{6 \times 74.55} \times 100 \%=96.66 \%
$$

Balance Delay

$$
\mathrm{BD}=\frac{(6 \times 74.55)-432.37}{6 \times 74.55} \times 100=3.45 \%
$$

Smoothness Index

$S I=\sqrt{1.76^{2}+\ldots+2.83^{2}}=6.62$

\section{Metode Kilbridge-Wester Heuristic}

Hasil perhitungan parameter performansi line dari metode Kilbridge-Wester Heuristic adalah sebagai berikut:

\section{Line Efficiency}

$\mathrm{LE}=\frac{71.17+73.8 \ldots+71.72}{6 \times 74.55} \times 100 \%=96.66 \%$

Balance Delay

$\mathrm{BD}=\frac{(6 \times 74.55)-432.37}{6 \times 74.55} \times 100=3.45 \%$

Smoothness Index

$S I=\sqrt{3.38^{2}+\ldots+2.83^{2}}=6.86$

\section{Metode Moodie Young}

Hasil perhitungan parameter performansi line dari metode Moodie Young adalah sebagai berikut:

$$
\begin{aligned}
& \text { Line Efficiency } \\
& \mathrm{LE}=\frac{71.17+73.8 \ldots+71.72}{6 \times 74.55} \times 100 \%=96.66 \%
\end{aligned}
$$$$
\text { Balance Delay }
$$

$$
\mathrm{BD}=\frac{(6 \times 74.55)-432.37}{6 \times 74.55} \times 100=3.45 \%
$$

Smoothness Index

$S I=\sqrt{3.38^{2}+\ldots+2.83^{2}}=6.86$

\section{Perbandingan Parameter Performansi Line}

Peningkatan performasi line welding 1DY merupakan hasil dari penelitian ini yang menggunakan beberapa indikator performansi untuk melihat seberapa baik tingkat performansi dari ketiga metode usulan. Tabel 4 merupakan hasil perbandingan indikator performansi awal dan performansi usulan pembentukan rancangan keseimbangan masing-masing metode. 
Tabel 4 Perbandingan indikator performansi

\begin{tabular}{|l|c|c|c|c|}
\hline $\begin{array}{c}\text { Indikator } \\
\text { performan } \\
\text { si }\end{array}$ & $\begin{array}{c}\text { K- } \\
\text { awal }\end{array}$ & $\begin{array}{c}\boldsymbol{H} \text { - } \\
\text { birnie }\end{array}$ & $\begin{array}{c}\text { Kilbridge } \\
\text {-ws }\end{array}$ & Moodie $\boldsymbol{y}$ \\
\hline $\begin{array}{l}\text { Jumlah } \\
\text { Stasiun } \\
\begin{array}{l}\text { Kerja } \\
\text { (Operator) }\end{array}\end{array}$ & 8 & 6 & 6 & 6 \\
\hline $\begin{array}{l}\text { Efficiency } \\
\text { Line }\end{array}$ & $\begin{array}{c}75.01 \\
\%\end{array}$ & $\begin{array}{c}96.66 \\
\%\end{array}$ & $96.66 \%$ & $96.66 \%$ \\
\hline $\begin{array}{l}\text { Balance } \\
\text { Delay }\end{array}$ & $\begin{array}{c}24.98 \\
\%\end{array}$ & $\begin{array}{c}3.45 \\
\%\end{array}$ & $3.45 \%$ & $3.45 \%$ \\
\hline $\begin{array}{l}\text { Smoothne } \\
\text { ss Index }\end{array}$ & 62.67 & 6.62 & 6.86 & 6.86 \\
\hline
\end{tabular}

Dilihat dari hasil tabel diatas, perbandingan seluruh indikator performansi pada kondisi awal lebih kecil dari pada ketiga metode usulan dimana ketiga metode usulan tersebut mengalami peningkatan yang cukup signifikan.

Ketiga metode usulan mempunyai hasil yang sama besar pada indikator performansi efficiency line dan balance delay, akan tetapi mempunyai hasil yang berbeda jika dilihat dari hasil smoothness index. Hasil smoothness index pada metode Helgeson-Birnie mempunyai hasil yang paling baik sehinggga metode tersebut merupakan metode yang terbaik untuk penelitian ini.

\section{Hasil Layout Kondisi Usulan}

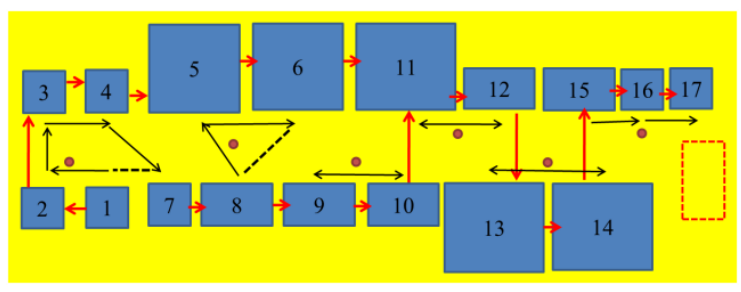

Gambar 2. Layout kondisi usulan line welding 1DY

Dimana:

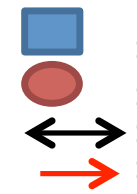

: ilustrasi dari mesin atau elemen kerja

: ilustrasi dari operator kerja

: ilustrasi dari pergerakan operator kerja

ilustrasi dari urutan proses kerja

Hasil layout line welding 1DY pada kondisi usulan dengan 6 stasiun kerja dan menggunakan 6 operator. Secara visual, posisi letak mesin pada line welding 1DY tersebut tetap, hanya pergerak operator saja yang berubah mengikuti jumlah elemen kerja pada setiap stasiun kerja yang dikerjakan.

\section{Kesimpulan}

Dari proses observasi dan analisis yang telah dilalui dari penelitian ini, dapat disimpulkan bahwa: a. Pembentukan rancangan dengan metode Helgeson-Birnie mampu memberikan solusi terbaik pada line welding 1DY.

b. Berkurangnya jumlah operator dengan memperkecil jumlah stasiun kerja yang semula 8 menjadi 6 (satu stasiun kerja ditangani oleh satu operator).

\section{Daftar pustaka}

Boysen, N., Malte Fliedner, dan Armin School. "A Classification of Assembly Line Balancing Problems". Europan Journal of Operation Research, 2007: 183.

Elsayed, E. A., dan Boucher, T.O. (1994). Analysis and Control of Production Systems. 2nd Edition. Englewood Cliffs, New Jersey: Prentice Hall International, Inc.

Purnomo, H. (2004). Pengantar Teknik Industri. Edisi Kedua. Yogyakarta: Graha IImu.

Wignjosoebroto, S. (2003). Teknik Tata Cara dan Pengukuran Kerja, Edisi ketiga Guna Widya, Surabaya. 
(halaman ini dibiarkan kosong) 